\title{
電磁誘導型振動発電機の発電電力に及ぼす磁気パラメータの影響評価
}

\author{
大西 敦郎*1, 高橋 博*1
}

\section{Evaluation of the effect of magnetic parameters on power of an electromagnetic induction type vibration power generator}

\author{
Atsuro ONISHI ${ }^{* 1}$ and Hiroshi TAKAHASHI ${ }^{* 1}$ \\ ${ }^{* 1}$ Toshiba Corporation \\ 1 Komukai Toshiba-cho, Saiwai-ku, Kawasaki 212-8582, Japan
}

Received: 17 March 2020; Revised: 12 June 2020; Accepted: 24 August 2020

\begin{abstract}
A vibration power generator produce electricity using environmental vibration, such as floor vibration caused by people walking, vibration caused by cars and trains, and factory piping vibrations. Electric power generated by the vibration power generator is expected to be an alternative to a power source (a battery or the like) used in IoT sensor or the like. There are various types of vibration power generation such as electromagnetic induction type, magnetostriction type, piezoelectric type and electrostatic type. We are paying attention to electromagnetic induction type among them. There have been many studies on electromagnetic induction type vibration power generators, and it can be expected that the generated power will increase depending on each application. However, there are few studies to increase the generated power in the simple configuration of the vibration generator, that is, the configuration using the one-degree-of-freedom oscillator consisting of the magnetic circuit and the spring. Therefore, we constructed a mathematical model that formulated the effect of the magnetic parameters of a vibration generator using a one-degree-of-freedom oscillator on the generated power, and obtained design guidelines for a magnetic circuit for increasing the generated power. Furthermore, the validity of the model was evaluated by comparing the power generation performance test using the prototype and the calculation.
\end{abstract}

Keywords : Energy harvest, Vibration power generator, Electromagnetic induction, Magnetic flux concentratation,

Design method, IoT, Independent power supply

\section{1. 緒言}

近年，IoT センサ等の自立電源として，環境振動（例えば，人体の振動，車や電車の振動，工場の配管の振動な ぞ）を利用して発電する振動発電機が注目されている，振動発電の方式には様々な種類が存在するが，筆者らは 電磁誘導方式に着目している. 電磁誘導型振動発電機の開発例として，二自由度質点系により広帯域化を図った 例（井上，2015），非線形ばねを用いて共振帯域の増加を図った例（千田，増田，2011），ジャイロ効果を利用し て運動エネルギの増大を図った例（石井他，2008）などがあり，それぞれ用途に応じて発電電力の増加が期待で きる.しかし，振動発電機のシンプルな構成，つまり，磁気回路と線形ばねからなる一自由度振動子を用いた構 成において発電電力の増加を図った研究例は少ない，そこで，一自由度振動子を用いた振動発電機の磁気パラメ 一タが発電電力に与える影響を定式化した数式モデルを導き，発電電力の増加に向けた磁気回路の設計指針を得 た．さらに，試作機を用いた発電性能試験と計算の比較によりモデルの有効性を検証した.

No.20-00078 [DOI:10.1299/transjsme.20-00078], J-STAGE Advance Publication date : 1 September, 2020

${ }^{* 1}$ 正員，（株）東芝 研究開発センター（甬212-8582 神奈川県川崎市幸区小向東芝町 1)

E-mail of corresponding author: atsuro.oonishi@toshiba.co.jp 


\section{2.＼cjkstart設計パラメータが発電電カに与える影響のモデル化}

\section{$2 \cdot 1$ 支配方程式}

電磁誘導型振動発電機は一般的に，磁気回路（磁石とコアで構成），コイルおよびばねから構成される。また， 磁気回路が振動するムービングマグネット型とコイルが振動するムービングコイル型があるが，発電性能に寄与 する振動子の質量が大きく，コイルの引出し線を固定して断線防止を図ることが容易であるため，筆者らは前者 に着目している．前者の場合，ばねにより支持された磁気回路の磁束が，筐体に固定されたコイルに対し相対的 に動くことにより発電する.図 1 にムービングマグネット型振動発電機の模式図を示す.

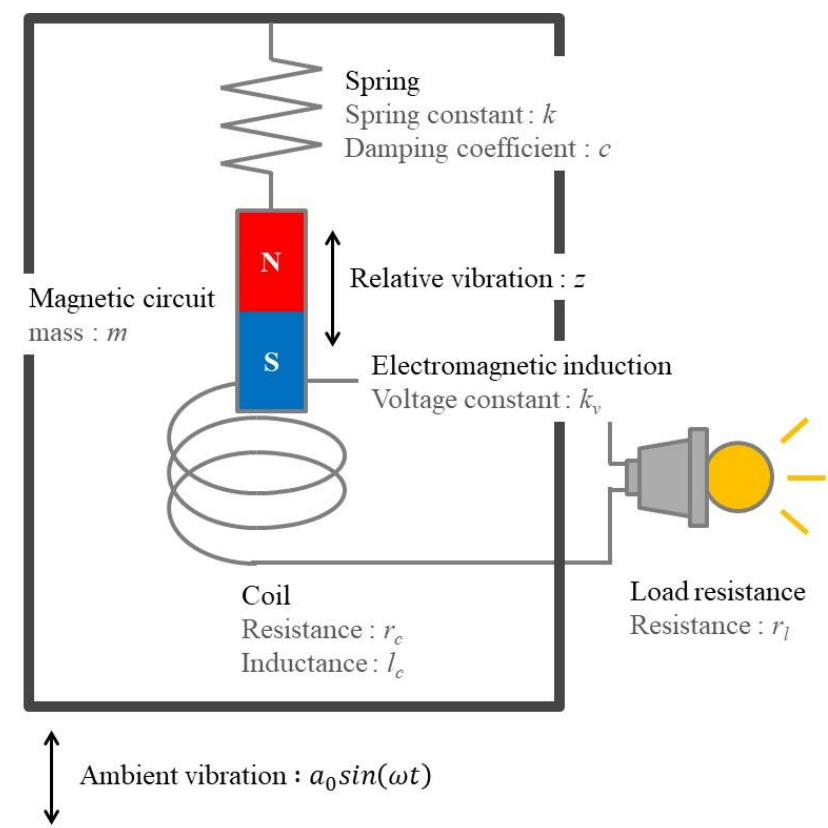

Fig. 1 Schematic diagram of a vibration power generator. The magnetic circuit vibrates due to environmental vibration. Power is generated by the relative movement of the coil fixed to the housing and the magnetic circuit.

式（1）と式（2）に，支配方程式を示す。ここで, 時間 $t$, 環境振動の加速度振幅 $a_{0}$, 環境振動の角周波数 $\omega$, 筐体に対する可動部の相対変位 $z$, 可動部の質量 $m$, 減衰係数 $c$, ばね定数 $k$, 電圧定数 $k_{v}$, 電流 $i$, コイル抵抗 $r_{c}$ ，コイルインダクタンス $l_{c}$ および負荷抵抗 $r_{l}$ である. なお，環境振動は正弦波と仮定した.

$$
\begin{aligned}
& m \frac{d^{2} z(t)}{d t^{2}}+c \frac{d z(t)}{d t}+k z(t)+k_{v} i(t)=m a_{0} \sin (\omega t) \\
& l_{c} \frac{d i(t)}{d t}+\left(r_{c}+r_{l}\right) i(t)=k_{v} \frac{d z(t)}{d t}
\end{aligned}
$$

振動発電機から取り出せる電力は負荷抵抗で消費される電力と等しい. したがって, 負荷抵抗での平均消費電 力を発電電力 (以降, 電力) $p$ と定義すると, 電力 $p$ は式（3）のように書ける. ここで， $\omega_{n}$ は固有角周波数であ る.

$$
p=\frac{r_{l} a_{0}{ }^{2} k_{v}{ }^{2} m^{2} \omega^{2}}{2\left(\left(r_{c}+r_{l}\right)^{2}+\omega^{2} l_{c}^{2}\right)\left(\left(-m \omega^{2}+m \omega_{n}^{2}+\frac{k_{v}{ }^{2} l_{c} \omega^{2}}{\left(r_{c}+r_{l}\right)^{2}+\omega^{2} l_{c}{ }^{2}}\right)^{2}+\omega^{2}\left(c+\frac{k_{v}{ }^{2}\left(r_{c}+r_{l}\right)}{\left(r_{c}+r_{l}\right)^{2}+\omega^{2} l_{c}{ }^{2}}\right)^{2}\right)}
$$


電力 $p$ が極大となる負荷抵抗 $r_{l}$ は, $\frac{d p}{d r_{l}}=0$ を $r_{l}$ について解くことで式 (4) のように書ける.

$$
r_{l}=\sqrt{r_{c}{ }^{2}+\omega^{2} l_{c}{ }^{2}+\frac{k_{v}{ }^{2} \omega^{2}\left(k_{v}{ }^{2}+2\left(c r_{c}+l_{c} m\left(-\omega^{2}+\omega_{n}{ }^{2}\right)\right)\right)}{c^{2} \omega^{2}+m^{2}\left(\omega-\omega_{n}\right)^{2}\left(\omega+\omega_{n}\right)^{2}}}
$$

図 2 に，負荷抵抗 $r_{l 1}, r_{l 2}, r_{l 3}$ （ただし， $r_{l 3}>r_{l 2}>r_{l 1}$ ）ごとの周波数に対する式（3）の計算例を示す. 表 1 に 計算諸元を示す. 負荷抵抗により電力の周波数応答が変化することが確認できる.

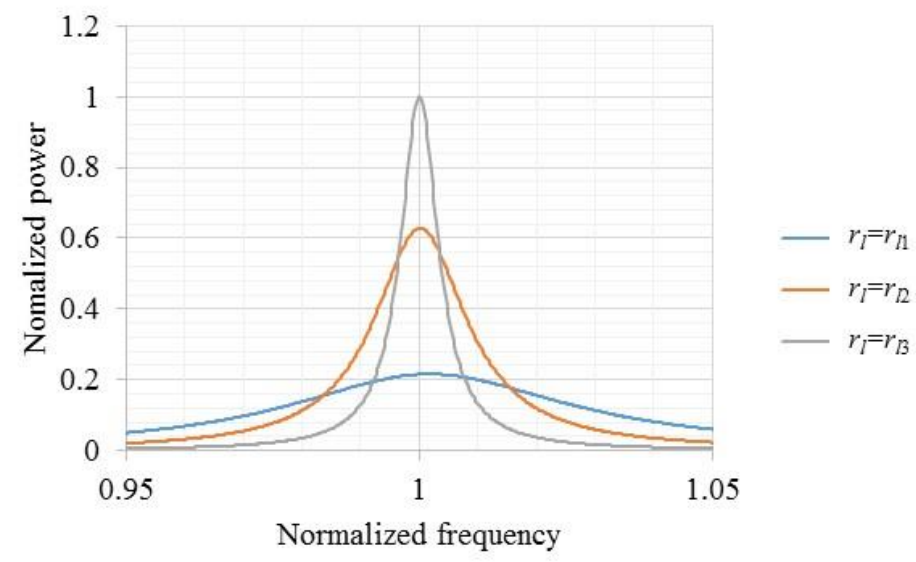

Fig. 2 Normalized power by Normalized frequency with each external resistance. The calculation results were calculated based on Eq. (3) using the following value. $m=0.7 \mathrm{~kg}, c=0.76 \mathrm{Ns} / \mathrm{m}, \omega_{n}=281 \mathrm{rad} / \mathrm{s}, k_{v}=245 \mathrm{Vs} / \mathrm{m}, r_{c}=780 \Omega, l_{c}=$ $1.29 \mathrm{H}, r_{l}=5000.0 \Omega, 20000 \Omega, 80000 \Omega, a_{0}=0.1 \mathrm{~m} / \mathrm{s}^{2}$. Frequency response of power changes due to load resistance.

Table 1 Calculation specification in Fig.2.

\begin{tabular}{l|l|l}
\hline \multicolumn{1}{c|}{ Parameter } & Variables & \multicolumn{1}{c}{ Value } \\
\hline Mass $[\mathrm{kg}]$ & $m$ & 0.7 \\
\hline Damping coffiecient $[\mathrm{N} \mathrm{s} / \mathrm{m}]$ & $c$ & 0.76 \\
\hline Natural angular frequency $[\mathrm{rad} / \mathrm{s}]$ & $\omega_{n}$ & 281 \\
\hline Voltage constant $[\mathrm{V} \mathrm{s} / \mathrm{m}]$ & $k_{v}$ & 245 \\
\hline Coil resistance $[\Omega]$ & $r_{c}$ & 780 \\
\hline Coil inductance $[\mathrm{H}]$ & $l_{c}$ & 1.29 \\
\hline Load resistance $[\Omega]$ & $r_{l}$ & $5000.0,20000,80000$ \\
\hline Vibration amplitude $\left[\mathrm{m} / \mathrm{s}^{2}\right]$ & $a_{0}$ & 0.1 \\
\hline
\end{tabular}

\section{$2 \cdot 2$ 磁気パラメータの影響}

環境振動の周波数が固有振動数と一致している場合，式（3）と式（4）はそれぞれ式（5）と式（6）のように 書ける.

$$
\begin{aligned}
& p=\frac{a_{0}{ }^{2} k_{v}{ }^{2} m^{2} r_{l}}{2\left(\left(k_{v}{ }^{2}+c\left(r_{c}+r_{l}\right)\right)^{2}+c^{2} \omega_{n}{ }^{2} l_{c}{ }^{2}\right)} \\
& r_{l}=\sqrt{\frac{\left(k_{v}{ }^{2}+c r_{c}\right)^{2}}{c^{2}}+\omega_{n}{ }^{2} l_{c}{ }^{2}}
\end{aligned}
$$


式（5）に式（6）を代入すると，式（7）のように書ける.

$$
p=\frac{a_{0}{ }^{2} k_{v}{ }^{2} m^{2}}{4 c\left(k_{v}{ }^{2}+c\left(r_{c}+\sqrt{\left(\frac{k_{v}{ }^{2}+r_{c}}{c}\right)^{2}+\omega_{n}{ }^{2} l_{c}{ }^{2}}\right)\right)}
$$

コイルのリアクタンス $\omega_{n} l_{c}$ が, 式 (7) の平方根内の $\frac{k_{v}{ }^{2}+c r_{c}}{c}$ よりも十分に小さいと仮定すると, 式 (7) は式 (8) のように書き直せる.

$$
p=\frac{m^{2} a_{0}^{2} k_{v}^{2}}{8 c\left(k_{v}^{2}+c r_{c}\right)}
$$

ここで, 図 3 のように, 磁束がコイルの半径方向に鎖交し, その平均鎖交磁束密度が可動部の移動によって変 化しない場合, 電圧定数 $k_{v}$ は, 式 (9) のように書ける (日本機械学会編, 1991). ここで, コイルの平均直径 $d$, 巻き数 $n$, コイルの平均鎖交磁束密度 $b$ である.

$$
k_{v}=\pi d n b
$$

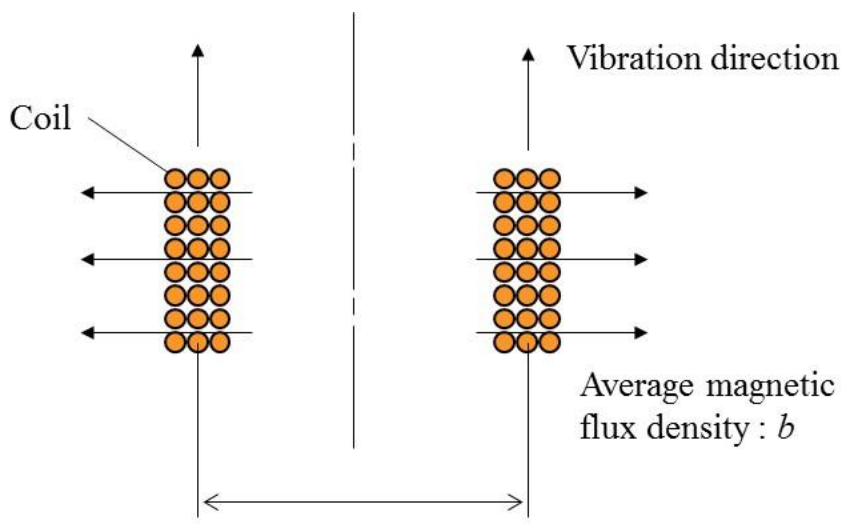

Average diameter : $d$

Fig.3 Schematic cross section of a coil and uniform magnetic flux density direction.

一方, コイル抵抗 $r_{c}$ は, コイルの巻き数 $n$ を用いて, 式 (10) のように書ける.ここで, 銅の抵抗率 $\rho$, コイル の導線径 $d_{w}$ である.

$$
r_{c}=\rho \frac{\pi d n}{\pi\left(\frac{d_{w}}{2}\right)^{2}}=\rho \frac{d n}{\left(\frac{d_{w}}{2}\right)^{2}}
$$

また，全導線の断面積合計 $S$ およびコイル体積は，それぞれ式（11）および式（12）のように書ける.

$$
\begin{aligned}
& S=\pi\left(\frac{d_{w}}{2}\right)^{2} n \\
& V=\pi d S
\end{aligned}
$$


したがって，コイル抵抗は式（13）のように書き直せる.

$$
r_{c}=\rho \frac{\pi^{2} d^{2} n^{2}}{V}
$$

さて，式（8）に，式（9）と式（13）を代入すると，式（14）のように書ける.

$$
p=\frac{m^{2} a_{0}^{2}}{8 c\left(1+\rho \frac{c}{b^{2} V}\right)}
$$

ここで，減衰比ろを用いると，式（14）は式（15）のように書き直せる.

$$
p=\frac{m a_{0}^{2}}{16 \zeta \omega_{n}\left(1+2 \rho \frac{\zeta m \omega_{n}}{b^{2} V}\right)}
$$

式（15）より，磁気回路の設計パラメータであるコイル体積 $V$ と平均鎖交磁束密度 $b$ を用いて電力を概算する ことができる. 寸なわち, 必要電力に応じた磁気回路の概略設計が可能となる. また, 電力 $p$ を大きくするには, 減衰比了を小さくし，コイル体積 $V$ と平均鎖交磁束密度 $b$ を大きくすれば良いことがわかる．しかし，コイル体 積 $V$ と平均鎖交磁束密度 $b$ はトレードオフの関係にあるため, 両方を大きくすることは難しい. そこで, 平均磁 束密度 $b$ をできるだけ増加させることを電力増加に向けた設計指針とした. ただし, 一般的に, 平均磁束密度 $b$ を大きくすればするほどコイルのインダクタンスは大きくなる.このとき，コイルのリアクタンス $\omega_{n} l_{c} か ゙ \frac{k_{v}{ }^{2}+c r_{c}}{c}$ よりも十分に小さいという仮定が成り立たなくなり，設計によっては近似による誤差が生じると考えられる，こ の点については，5章において試作機の実測と計算の比較を通じて議論する.

さらに, 平均鎖交磁束密度 $b$ を増加させると, 式 (14) は式 (16) に漸近し, 理論上の最大電力となる (鈴 木, 2008).

$$
p=\frac{m^{2} a_{0}^{2}}{8 c}
$$

図 4 に，コイル体積 $V_{1} ， V_{2}, V_{3}$ （ただし， $V_{3}>V_{2}>V_{1}$ ）ごとの平均鎖交磁束密度に対する式（14）の計算例を 示寸．表 2 に計算諸元を示す．なお，グラフの縦軸は式（16）に基づき正規化した．平均鎖交磁束密度の増加に より電力が増加することが確認できる. また, コイル体積の増加により, 平均鎖交磁束密度が小さい領域におい て傾きが増加することが確認できる. 


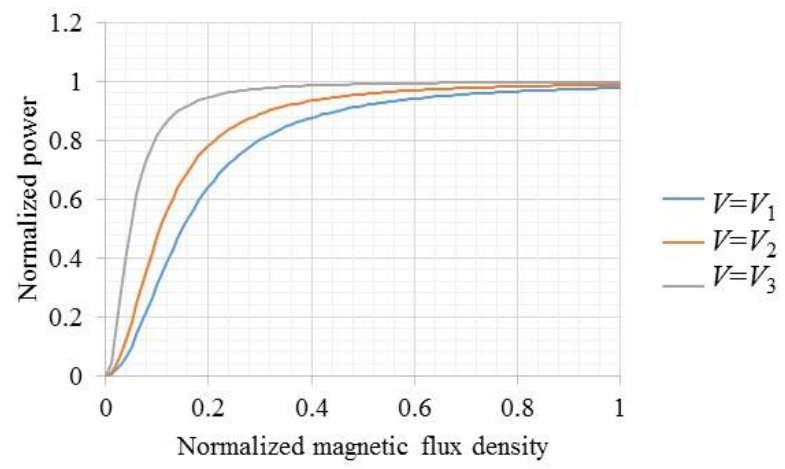

Fig. 4 Normalized power by normalized magnetic flux density. The calculation results were calculated based on Eq. (14) using the following values. $m=0.7 \mathrm{~kg}, c=0.76 \mathrm{Ns} / \mathrm{m}, \rho=1.68 \times 10^{-8} \Omega \mathrm{m}, V=575.0 \mathrm{~mm}^{3}, 2873 \mathrm{~mm}^{3}, 5745 \mathrm{~mm}^{3}, a_{0}=0.1$ $\mathrm{m} / \mathrm{s}^{2}$. The vertical axis of the graph is normalized based on Eq. (16). The power increases as the average flux linkage density increases. Also, as the coil volume increases, the slope increases in the region where the average flux linkage density is small.

Table 2 Calculation specification in Fig.4.

\begin{tabular}{l|l|l}
\hline \hline \multicolumn{1}{c|}{ Parameter } & Variables & \multicolumn{1}{c}{ Value } \\
\hline Mass $[\mathrm{kg}]$ & $m$ & 0.7 \\
\hline Damping coffiecient $[\mathrm{N} \mathrm{s} / \mathrm{m}]$ & $c$ & 0.76 \\
\hline Resitibity of copper $[\Omega \mathrm{m}]$ & $\rho$ & $1.68 \times 10^{-8}$ \\
\hline Coil volume $\left[\mathrm{mm}^{3}\right]$ & $V$ & $575.0,2873,5745$ \\
\hline Vibration amplitude $\left[\mathrm{m} / \mathrm{s}^{2}\right]$ & $a_{0}$ & 0.1 \\
\hline
\end{tabular}

\section{3. 試 作}

図 5 に, 設計した振動発電機の断面模式図と試作機の写真を示寸，振動発電機は，磁気回路，ばね, 環状コイ ルおよび筐体で構成した．環状コイルは筐体に固定した．磁気回路はばねにより支持され，外部から環境振動が 加わると上下方向に振動する. 発電部の寸法は直径 $71 \mathrm{~mm}$, 高さ $65 \mathrm{~mm}$ 程度である. 表 3 に試作機の物理パラメ ータを示す。
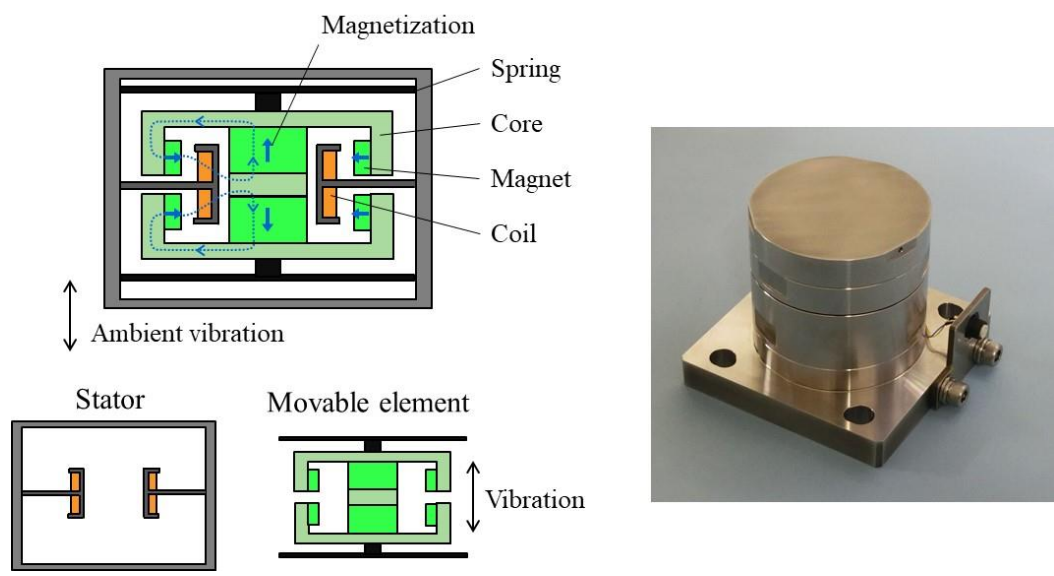

Fig. 5 Schematic diagram of the design and Prototype photo. The size of the power generator section is $\varphi 71 \mathrm{~mm}$ and the height is about $65 \mathrm{~mm}$. 
Table 3 Characteristic values of the prototype.

\begin{tabular}{l|l|l}
\hline \multicolumn{1}{c|}{ Parameter } & Variables & \multicolumn{1}{c}{ Value } \\
\hline Mass [kg] & $m$ & 0.7 \\
\hline Coil resistance $[\Omega]$ & $r_{c}$ & 780 \\
\hline Coil inductance $[\mathrm{H}]$ & $l_{c}$ & 1.29 \\
\hline Coil average diameter [mm] & $d$ & 38.5 \\
\hline Number of turns [turn] & $n$ & 4200 \\
\hline Coil volume $\left[\mathrm{mm}^{3}\right]$ & $V$ & 5745 \\
\hline
\end{tabular}

\section{4. 数式モデルの有効性検証}

\section{$4 \cdot 1$ 発電性能の評価方法}

振動発電試作機の発電性能を評価するために，正弦波による振動試験を実施した．図 6 に振動試験の様子と試 験構成を示す．加速度計によるフィードバック制御を備えた動電式振動試験装置に試作機を設置し，試作機に接 続した負荷抵抗間の電圧をオシロスコープで測定した. 測定した電圧から負荷抵抗における消費電力を算出し, 試作機の電力とした. 試験は以下の 2 種類を実施した. 試験 1 は, 式（3）の有効性を検証するために実施し, 試 験 2 は, 式（14）の有効性, つまり, 磁気回路の設計パラメータから電力を見積もることができるかを検証する ために実施した。

試験 1 : 加振周波数 $43.00 \mathrm{~Hz}$ から $47.00 \mathrm{~Hz}$ を $0.20 \mathrm{~Hz}$ 刻み, 加振振幅 $0.1 \mathrm{~m} / \mathrm{s}^{2}$ 負荷抵抗をパラメータとし， $9950.0 \Omega ， 20000 \Omega, 50900 \Omega$

試験 2 : 加振周波数 $44.75 \mathrm{~Hz} ，$ 加振振幅 $0.1 \mathrm{~m} / \mathrm{s}^{2}$ ，負荷抵抗 $82100 \Omega$

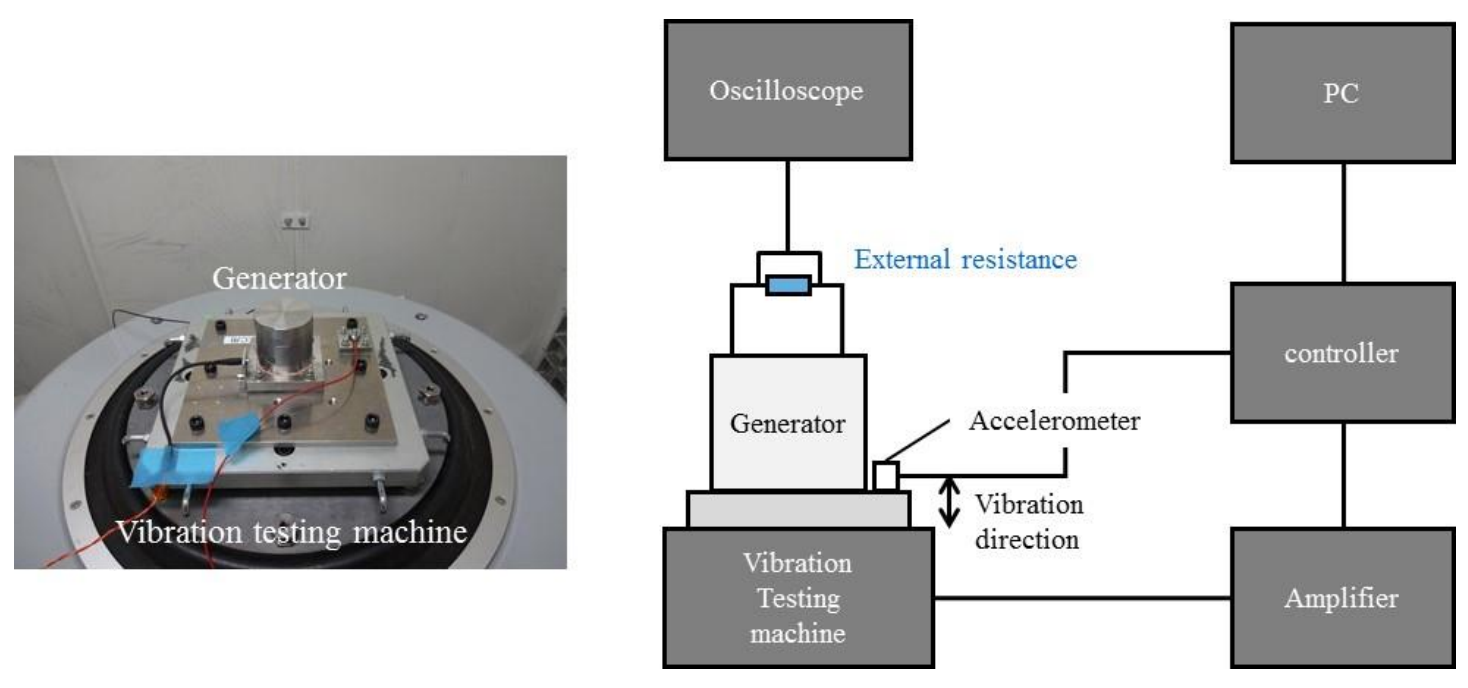

Fig.6 Photo of the vibration test and test configuration.

\section{$4 \cdot 2$ 試験結果と計算結果の比較}

まず, 試験 1 について, 試験結果と計算結果との二乗誤差が最小化するように, 減衰係数 $c$, 固有振動数 $\omega_{n}$, 電圧定数 $k_{v}$ を推定した. また, 電圧定数の推定值と表 3 の值を用いて, 式 (9) から平均鎖交磁束密度を算出する と $0.48 \mathrm{~T}$ となった. 表 4 に推定したパラメータを示寸. 
図 7 に，試験 1 の試験結果と計算結果を比較したグラフを示す.計算結果は，表 3 と表 4 のパラメータ值と加 振振幅 $0.1 \mathrm{~m} / \mathrm{s}^{2}$ を用いて式（3）より算出した. 試験結果と計算結果は良い一致を示したことから, 式 (3) が妥当 であることを確認した。

Table 4 Estimate values of the prototype.

\begin{tabular}{l|l|l}
\hline \hline \multicolumn{1}{c|}{ Parameter } & \multicolumn{1}{c|}{ Variables } & Estimate value \\
\hline Damping coffiecient $[\mathrm{N} \mathrm{s} / \mathrm{m}]$ & $c$ & 0.76 \\
\hline Natural angular frequency $[\mathrm{rad} / \mathrm{s}]$ & $\omega_{n}$ & 281 \\
\hline Voltage constant $[\mathrm{V} \mathrm{s} / \mathrm{m}]$ & $k_{v}$ & 245 \\
\hline Flux density $[\mathrm{T}]$ & $b$ & 0.48 \\
\hline
\end{tabular}

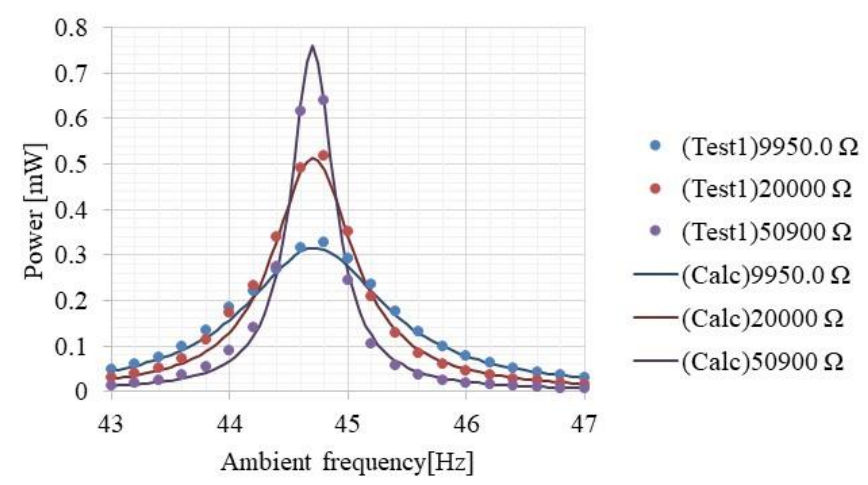

Fig. 7 Measurement and calculation ( Test1 ). The calculation results were calculated based on Eq. (3) using the following values. $m=0.7 \mathrm{~kg}, c=0.76 \mathrm{Ns} / \mathrm{m}, \omega_{n}=281 \mathrm{rad} / \mathrm{s}, k_{v}=245 \mathrm{Vs} / \mathrm{m}, r_{c}=780 \Omega, l_{c}=1.29 \mathrm{H}, r_{l}=9950.0 \Omega, 20000 \Omega$, $50900 \Omega, a_{0}=0.1 \mathrm{~m} / \mathrm{s}^{2}$. The test and calculation results showed good agreement.

つぎに，図 8 に，試験 2 の試験結果と計算結果を比較したグラフを示す. 図中の試験結果は，表 4 の平均鎖交 磁束密度の推定值 $0.48 \mathrm{~T}$ と, 発電電力の試験結果 $0.79 \mathrm{~mW}$ に基づいてプロットした. 計算結果は, 表 3 と表 4 の パラメータ值と加振振幅 $0.1 \mathrm{~m} / \mathrm{s}^{2}$ を用いて式（14）より求めた. 図 8 より, 試験結果は, ほぼ計算曲線上に位置 することが確認された. なお，計算は環境振動の周波数=固有振動数 $44.70 \mathrm{~Hz}$ （角振動数 $281 \mathrm{rad} / \mathrm{s}$ 相当）とした のに対し，試験は都合上， $44.75 \mathrm{~Hz}$ で実施したため相違がある.このため，本来であれば試験結果と計算結果を 同時に記載すべきではないが，本比較の目的は式（14）の有効性を試験結果から検証することであり問題はない と考える.

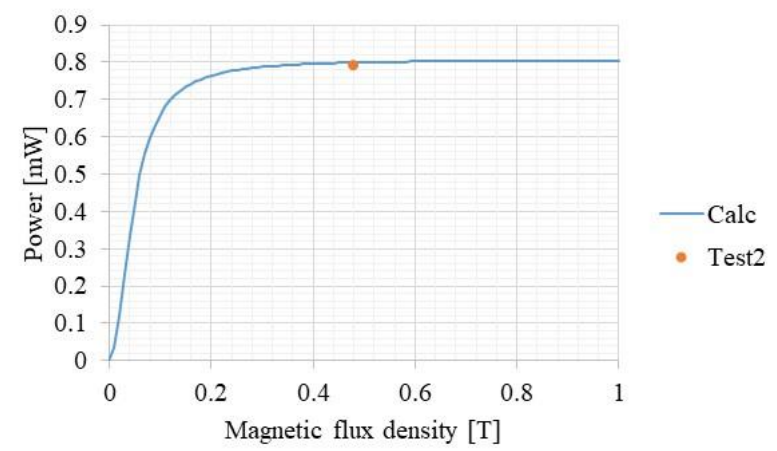

Fig. 8 Measurement and calculation ( Test2). The calculation results were calculated based on Eq. (14) using the following values. $m=0.7 \mathrm{~kg}, c=0.76 \mathrm{Ns} / \mathrm{m}, \rho=1.68 \times 10^{-8} \Omega \mathrm{m}, V=5745 \mathrm{~mm}^{3}, a_{0}=0.1 \mathrm{~m} / \mathrm{s}^{2}$. The test and calculation results showed good agreement. 
また, 図 9 に, 表 3 と表 4 のパラメータ值を用いて計算した式 (7) と式 (14) の結果を示す. 式 (7) と式 (14) の計算結果にはほとんど違いがないことが確認された。これにより，式（14）が有効な近似式であることが確か められた.

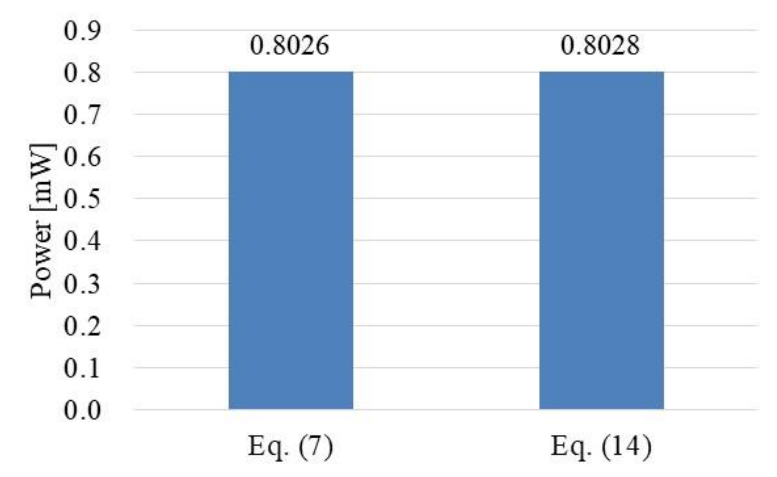

Fig. 9 The calculation results were calculated based on Eq. (7) and Eq. (14) using the following values. $m=0.7 \mathrm{~kg}, c=0.76$ $\mathrm{Ns} / \mathrm{m}, \omega_{n}=281 \mathrm{rad} / \mathrm{s}, k_{v}=245 \mathrm{Vs} / \mathrm{m}, r_{c}=780 \Omega, l_{c}=1.29 \mathrm{H}, \rho=1.68 \times 10^{-8} \Omega \mathrm{m}, b=0.48 \mathrm{~T}, V=5745 \mathrm{~mm}^{3}, a_{0}=0.1$ $\mathrm{m} / \mathrm{s}^{2}$. There was almost no difference between the calculation results of Eq. (7) and Eq. (14).

\section{5. 結}

磁気回路の設計パラメータが発電電力に与える影響を明確化した数式モデルを導き, 電力増加に向けた磁気回 路の設計指針を得た。また，試作機を用いた発電性能試験の結果と計算結果が良い一致を示したことから，モデ ルの有効性を検証できた. 本検証により, 電磁誘導型振動発電機の発電電力の増加に向けた設計指針を獲得でき た.

\section{文献}

井上竜太, 設備振動を電力に変換するワイドバンド型振動発電技術の開発, 日本建築学会技術報告集, Vol.21,

No.49 (2015), pp.1097-1100.

石井智裕, 後藤裕治, 小川達也, 保坂寛, ジャイロ型振動発電機の研究, 精密工学会誌, Vol.74, No.7 (2008), pp.764768.

千田温子, 増田新, 自励発振特性を有する 1 自由度非線形振動子を用いた振動発電, Dynamics \& Design

Conference, Vol.2011 (2011), セッションID112.

鈴木雄二, マイクロ環境発電デバイスの研究動向, 電気学会誌, Vol.128, No.7 (2008), pp.435-438.

日本機械学会編, 機械系の動力学, オーム社 (1991), pp.142-143.

\section{References}

Inoue, R., Development of vibration energy harvester using building equipment, AIJ Journal of Technology and Design, Vol.21, No.49 (2015), pp.1097-1100 (in Japanese).

Ishii, T., Goto, Y., Ogawa, T. and Hosaka, H., Development of gyroscopic power generator, Journal of the Japan Society of Precision Engineering, Vol.74, No.7 (2008), pp.764-768 (in Japanese).

Senda, O. and Masuda, S., Vibration energy harvesting using a nonlinear SDOF oscillator with self-excitation capability, Dynamics \& Design Conference, Vol.2011 (2011), ID 112 (in Japanese).

Suzuki, Y., Research trend of micro energy harvesting device, The Journal of The Institute of Electrical Engineers of Japan, Vol.128, No.7 (2008), pp.435-438 (in Japanese).

The Japan Society of Mechanical Engineers ed., Mechanical system dynamics, Ohmsha, Ltd. (1991), pp.142-143 (in Japanese). 